\title{
Rubber production incentive scheme (RPIS) for cultivators and its effectiveness in Kasaragod district
}

\author{
N. Karunakaran ${ }^{1 *}$, Jeeshma Vijayan VP² \\ ${ }^{1} \mathrm{HOD},{ }^{2}$ Post-Graduate Student, ${ }^{\mathbf{1} 2}$ Dept. of Economics, ${ }^{\mathbf{1 , 2}}$ Ek Nayanar Memorial Government College Elerithattu, Kasaragod, Kerala, India \\ *Corresponding Author: N. Karunakaran \\ Email: narankarun@gmail.com
}

\begin{abstract}
Cultivation of rubber was spread widely during the last 25 years in Kerala and is the second largest crop. The wide spread of rubber shows that around 90 percent of natural rubber in India is contributed by Kerala. The economic development of any nation depends on industries including agro based industries. Rubber industry is one of the important agro-based industries and natural rubber producers faced many problems relating to its price. Government has introduced many schemes for the development of this crop and Rubber Production Incentive Scheme (RPIS) is a programme which guarantees a minimum price of Rs.150 per kilogram for rubber. There has been a slight change in the area of rubber after this and the study reached a conclusion that farmers are effectively managing their costs through this scheme.
\end{abstract}

Keywords: Rubber, RPIS, Small rubber cultivators; Effectiveness, Kasaragod.

\section{Introduction}

Rubber is a major plantation crop in Kerala and many people depends on the cultivation of it. State ranks first in the country's total natural rubber production. It has become the main source of income for many farmers. Among the districts in Kerala, Kottayam is the leader in rubber production. Rubber plantation has provided more stable income for rural households and many people depend on its cultivation.

Government has implemented lot of schemes for the development of this crop and Rubber Production Incentive Scheme (RPIS) was introduced in 2015. Under this scheme, a maximum of 150 kilogram per hectare per month at a price of Rupees 150 per kilogram, that is, at a higher price than current prices is bought from a grower and the difference is paid as subsidy. The study focused on the effectiveness of this Scheme on rubber cultivators in

Kerala especially in Kasaragod district. The main objective of this paper includes:

1. To analyze various rubber production incentive schemes to farmers.

2. To bring about the changes in area, production and productivity of rubber as a result of the scheme; and

3. To study how the farmers effectively manage the cost of rubber production through Rubber Production Incentive Scheme.

\section{Materials and Methods}

Nageswara Rao DVK, et al. (2002), Karunakaran N (2013) and Shahul Hameed M (2014) studied about the role of rubber producers societies in Kerala. Jogjith Sangal, et. al. (2015) and Mathiraj S P and Bindu T V (2015) conducted a study about socio-economic condition of rubber plantation workers. Shyni Alexander T and Beth Haren (2016) investigated about the problems and prospects of rubber plantation industries in Kerala. Aravindan (2018) and Krishnakumar PK (2019) discussed about untapped estates by rubber board. The study used both primary and secondary data. Primary data was collected from 60 farmers of rubber in the Kasaragod district and secondary data from various published and un-published reports related to rubber farming.

\section{Results and Discussion}

Rubber and its products are indispensable part of our life. In the day today life, a life passing without using any of the rubber products is unbelievable. India is the world's largest producer and the third largest consumer of natural rubber and is also one of the fastest growing economies globally with a stable annual growth (Binitha M and Johnm Mano Raj S, 2018). Production of rubber in the world was considered to be very unstable during the last few years (Krishna Kumar P $K, 2019)$. Indian rubber producing areas are divided in to two zones traditional and non-traditional. Traditional zones are Kanyakumari in Tamil Nadu and districts of Kerala. Nontraditional zones are coastal regions of Karnataka, Goa, Andhra Pradesh, Odisha, some areas of Maharashtra, North eastern states (mainly Tripura) and Andaman and Nicobar Islands. 90 percent of India's total production of natural rubber is contributed by Kerala.

Among the districts in Kerala, Kottayam is the leader in rubber production. Kerala holds a dominant position both in area of cultivation and production of natural rubber in India (Table 1). Many people depend on rubber cultivation; rubber tappers, farmers and others received income during the period.

\section{Various Incentive Schemes}

In Kerala Government has implemented different schemes for protecting rubber cultivators. It includes:

1. Rubber Plantation Development Scheme (RPDS): This scheme aimed at promoting rubber plantation in a scientific way, adopting recommended package of practices. An amount of Rs. 20000 per hectare is paid in six annual installments for holdings up to 5 hectare and Rs. 16000 per hectare; in six annual installments for holdings above 5 hectare and up to 20 hectare.

2. Labour Welfare Scheme (LWS): This scheme is given for the tappers of rubber farming; under this scheme 
tappers had housing subsidy, scholarship, insurance and labour welfare scheme.

3. Scheme for Rubber Rollers: This is provided for the people in SC, ST category.

4. Rubber Production Incentive Scheme (RPIS): Kerala government has provided the scheme for small scale rubber farmers to encourage them to increase production.
Under this scheme, the government buys a maximum of 150 kilogram per hectare from a grower per month at a price of Rs 150 per kilogram which is higher than current prices and the difference is paid as subsidy. Unlike other scheme, the payment is made online directly to the farmers.

Table 1: Area, Production and Productivity of principal crops in Kerala.

\begin{tabular}{|c|l|c|c|c|c|c|c|}
\hline \multirow{2}{*}{$\begin{array}{c}\text { NI. } \\
\text { No. }\end{array}$} & Crops & \multicolumn{2}{|c|}{$\begin{array}{c}\text { Area } \\
\text { (hectare) }\end{array}$} & \multicolumn{2}{c|}{$\begin{array}{c}\text { Production } \\
\text { (Tonne) }\end{array}$} & \multicolumn{2}{c|}{$\begin{array}{c}\text { Productivity } \\
\text { (kg./hectare.) }\end{array}$} \\
\cline { 3 - 8 } & & $\mathbf{2 0 1 7 - 1 8}$ & $\mathbf{2 0 1 8 - 1 9}$ & $\mathbf{2 0 1 7 - 1 8}$ & $\mathbf{2 0 1 8 - 1 9}$ & $\mathbf{2 0 1 7 - 1 8}$ & $\mathbf{2 0 1 8 - 1 9}$ \\
\hline 1 & Rice & 171398 & 189086 & 436483 & 521310 & 2547 & 2757 \\
\hline 2 & Pulses including Tur & 1738 & 1992 & 1711 & 2045 & 984 & 1027 \\
\hline 3 & Pepper & 85207 & 85141 & 34065 & 37955 & 400 & 446 \\
\hline 4 & Ginger & 5151 & 4370 & 20478 & 18979 & 3976 & 4343 \\
\hline 5 & Turmeric & 2632 & 2777 & 6506 & 8822 & 2472 & 3177 \\
\hline 6 & Cardamom & 39080 & 39080 & 17147 & 18350 & 439 & 470 \\
\hline 7 & Areca nut & 97696 & 94580 & 116839 & 108516 & 1196 & 1147 \\
\hline 8 & Banana & 57158 & 62106 & 489322 & 565829 & 8561 & 9111 \\
\hline 9 & Other plantains & 57140 & 54455 & 395806 & 379683 & 6927 & 6972 \\
\hline 10 & Cashew nut & 41661 & 39720 & 27944 & 25629 & 671 & 645 \\
\hline 11 & Tapioca & 68664 & 70193 & 2529729 & 2697319 & 36842 & 38427 \\
\hline 12 & Coconut & 781496 & 760443 & 5384 & 5230 & 6889 & 6878 \\
\hline 13 & Coffee & 84976 & 84976 & 63476 & 66465 & 747 & 782 \\
\hline 14 & Tea & 30205 & 30205 & 61505 & 62230 & 2036 & 2060 \\
\hline 15 & Rubber & 551050 & 551115 & 540400 & 540775 & 981 & 981 \\
\hline Source: Directorate of Economics and Statistics, Govt. of India. & & \\
\hline
\end{tabular}

The price for one kilogram of natural rubber was fluctuating during the months of 2019-20 (Figure 1). Table 2 explained the change in area, production and productivity of rubber. Area of rubber production has increased over the years.

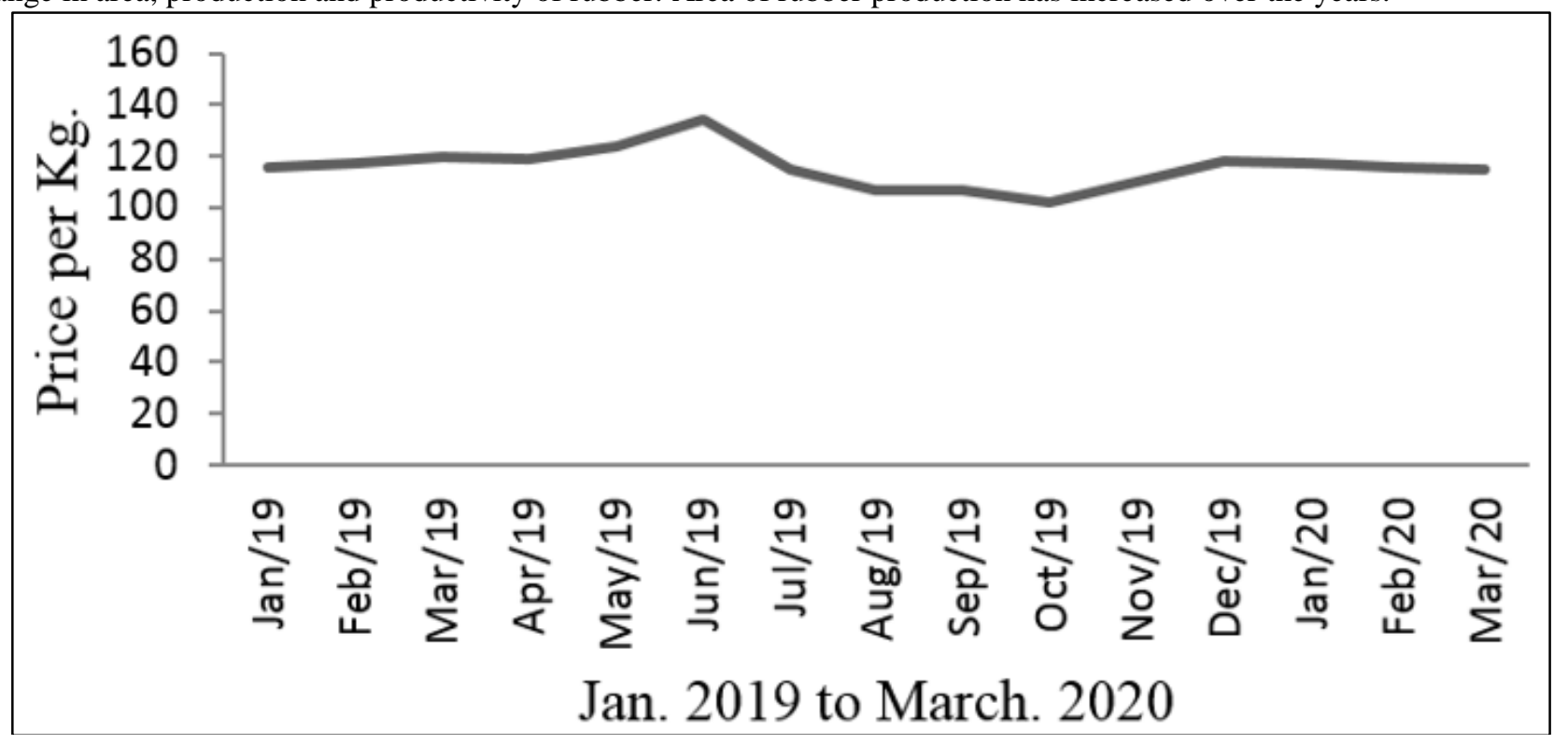

Fig. 1: Price of Natural rubber during 2019-20. 
Table 2: Area, Production and Productivity of rubber in Kerala.

\begin{tabular}{|c|c|c|c|}
\hline Year & Acre (hectare) & Production (tonne) & Productivity (kg/hectare) \\
\hline $2010-11$ & 525408 & 745510 & 1419 \\
\hline $2011-12$ & 534230 & 770580 & 1442 \\
\hline $2012-13$ & 539565 & 798890 & 1462 \\
\hline $2013-14$ & 539565 & 800050 & 1478 \\
\hline $2014-15$ & 548225 & 648220 & 1350 \\
\hline $2015-16$ & 549955 & 507770 & 1246 \\
\hline $2016-17$ & 550840 & 438630 & 796 \\
\hline $2017-18$ & 551050 & 540400 & 981 \\
\hline $2018-19$ & 551115 & 540775 & 981 \\
\hline \multicolumn{4}{|l}{ Source: Agricultural Statistics, Govt. of Kerala. } \\
\hline
\end{tabular}

Table 3 show costs for production of rubber in the study area. Most of the cultivators ( 52 percent) have the cost below Rs 50000; 38 percent have the cost between Rs 50001-100000.

Table 3: Costs for rubber cultivation in the study area.

\begin{tabular}{|l|c|}
\hline Costs (in Rupees) & Percentage of farmers \\
\hline Below 50000 & 52.0 \\
\hline $50001-100000$ & 38.0 \\
\hline $100001-150000$ & 6.0 \\
\hline $150001-200000$ & 4.0 \\
\hline Total & 100.0 \\
\hline Source: Primary data & \\
\hline
\end{tabular}

Table 4 explained the income received to farmers before and after the incentive scheme. Before the scheme implemented 16 percent of farmers received income below Rs. 50000; since the scheme, it is reduced to two percent. Between Rs. 50000100000 , it is 72 percent before the scheme, 54 percent after the scheme and income between Rs. 100001-150000, 32 percentage farmers have more income benefited due to the scheme.

Table 4: Income received before and after the incentive scheme in the study area.

\begin{tabular}{|l|c|c|c|}
\hline $\begin{array}{l}\text { Income } \\
\text { (in Rupees) }\end{array}$ & $\begin{array}{l}\text { Total income without incentive } \\
\text { scheme (Percentage of farmers) }\end{array}$ & $\begin{array}{l}\text { Total income with incentive } \\
\text { scheme (Percentage of farmers) }\end{array}$ & $\begin{array}{l}\text { Percentage } \\
\text { difference }\end{array}$ \\
\hline Below 50000 & 16.0 & 2.0 & $(-) 14$ \\
\hline $50000-100000$ & 72.0 & 54.0 & $(-) 18$ \\
\hline $100001-150000$ & 12.0 & 44.0 & $(+) 32$ \\
\hline Total & $\mathbf{1 0 0 . 0}$ & $\mathbf{1 0 0 . 0}$ & - \\
\hline
\end{tabular}

\section{Conclusion}

Rubber industry is one of the important agro-based industries in India and Kerala. Rubber cultivators faced many problems relating to the price of rubber. Therefore the Rubber Production Incentive Scheme was implemented. The study revealed that Government has implemented many schemes for rubber producers. The implementation of Rubber Production Incentive Scheme has slight change in the area of rubber. This scheme also helped the cultivators for increasing their total income and effectively manages the cost of production.

\section{Source of Funding}

None.

\section{Conflicts of Interest}

None.

\section{References}

1. Aravindan."Viability Key to Sustainability b of Rubber Cultivation", The Hindu, Jan 11, 2018.

2. Binitha M, Raj SJM. "Socio-Economic Conditions of Rubber Plantation Labourers Kanyakumari district", J Business Manag. 2018;20(3):35-40.

3. Singh J. "Socio Economic Conditions of Rubber Plantation Workers of Diphu, Karbi”, J Stud Manag Plan. 2015;1(9):42034

4. Karunakaran N. "Shift of Rubber Cultivation and Consequences on Environment and Food security in Kerala", $J$ Rural Dev. 2013;32(4):395-408.

5. Krishnakumar PK. "Adoption of un tapped estates by Rubber Board”, ET Beureau 2019.

6. Mathiraj SP, Bindu TV. "Problems Faced by Natural Rubber Cultivators", Int J Eng Manag Res. 2015;5(5):236-8.

7. Rao DVNK, Meti S, Nair ANS, Punnoose K.I. "Development of Rubber Information System", A Project on Development of Rubber Information System", Research Gate: 2002;3-6. 
8. Hameed SM. "Role of Rubber Producers Societies in Kerala", Int J Curr Res Acad Rev.2014;2(2):159-66.

9. Meti S, Rao DVKN, Nair UN and Jacob J. "Distribution of Natural Rubber Cultivation in relation to Soil and Landscape Attributes in India", Research Gate:2008;2-11.

10. Shyni Alexander T and Beth Haren. "Decline in Rubber price in Kerala", J Econ Soc Dev.2016;12(2):87-96.
How to cite: Karunakaran N, Vijayan JVP. Rubber Production Incentive Scheme (RPIS) for cultivators and its effectiveness in Kasaragod district. J Manag Res Anal. 2020;7(2):64-7. 